\title{
A Century of Astronomy at The Thacher School
}

Chris Vyhnal ${ }^{1 *}$, Jon Swift ${ }^{1}$

\begin{abstract}
The Thacher School has a rich legacy of education and research in astronomy that dates back over a century to correspondence in 1906 between our founder, Sherman Thacher, and the Director of the Mt. Wilson Observatory, George Hale. Nobel prize winning physicist Robert Millikan served on the School's Board of Trustees and conducted cosmic ray measurements on our campus in 1928. From 1930 to 1941 students and faculty from the School took annual trips to Pasadena to see the 100-inch Hooker telescope at Mt. Wilson and tour the Huntington Library and Caltech. Edwin Hubble gave the commencement address on our campus in 1942 and aluminized the mirror of an 8-inch telescope at the request of one of our students 10 years later. The Summer Science Program (SSP), which brought together some of the nation's brightest math and science students to participate in an intensive, 6-week immersion in astronomy, operated on our campus for 40 years starting in 1959. A 24-inch astrograph built by Caltech was installed in an observatory building erected on our campus by UCLA in 1965 and was later used for preliminary testing of the UCSD Digicon spectrographs that were eventually installed on the Hubble Space Telescope. In 1999 the School ceased its affiliation with the SSP and the program relocated, leaving behind an empty observatory building. With the recent renovation of our observatory, including the installation of a fully automated $0.7 \mathrm{~m}$ telescope and a cooled, back-illuminated CCD camera, the School has recaptured its rich historical legacy and renewed its commitment to student education and research in astronomy.
\end{abstract}

\section{Keywords}

The Thacher School; George Hale; Mt. Wilson Observatory; Robert Millikan; Edwin Hubble; Summer Science Program (SSP)

${ }^{1}$ The Thacher School, 5025 Thacher Road, Ojai, CA 93023

*Corresponding author: cvyhnal@thacher.org

\section{Introduction}

The Thacher School is a private, coeducational, residential, high school of 260 students nestled in the foothills of the Los Padres National Forest in Ojai, CA. It was originally established as a boys school in 1889 by Sherman Day Thacher who served as its Headmaster through the School's incorporation in 1924 until his retirement in 1931. The Thacher School began admitting girls in 1977 and is now the oldest coeducational boarding school in California.

\section{George Ellery Hale and the Origins of Astronomy at The Thacher School}

Astronomy became part of The Thacher School's educational culture almost from its inception. In late February and early March of 1906, Sherman Thacher wrote George Ellery Hale, Director of the Mount Wilson Solar Observatory in Pasadena, to obtain a reference for prospective student Seward C. Simons. In this initial correspondence, Thacher added: 
"If you can ever spare the time for a visit to the Ojai, I need not say how much pleasure it would give us to have you stay with us. Perhaps you would give our boys a little astronomical inspiration, if you can come." (Thacher, 1906, 2/22)

Thacher wrote Hale again in May of 1911 with an invitation to speak at the School's commencement:

\begin{abstract}
"The subject of the lecture might be anything that would seem to you appropriate for such an occasion and for the audience, which would consist primarily of the boys of this school, from thirteen to nineteen years of age, the teachers, a few parents, and our neighbors in the valley. We are not capable of comprehending very deep or technical things, and such a talk should be distinctly 'popular,' I suppose, but I should like to have them have a chance to observe the greatness of real scientific work." (Thacher, 1911, 5/11)
\end{abstract}

Hale was apparently away in Europe at the time and did not reply. Thacher tried once again to obtain Hale for the commencement address the next year (Thacher, 1912, 2/23), but Hale declined, writing:

"I ought to add that, in any event, Commencement addresses are decidedly out of my line and hitherto I have always declined to give one. Perhaps, however, I can give the boys an illustrated talk some time next year on the work of the Observatory, if you care to have one." (Hale, 1912, 2/28)

There is, however, no evidence in the calendar of the School's yearbook, the El Archivero, or in the School newspaper, The Thacher Notes, that Hale actually came to speak at the School during the 1912-1913 school year. Nevertheless, Thacher and Hale continued their correspondence as their relationship deepened. Their daughters were schoolmates together at Miss Ransom and Miss
Bridges' School in San Francisco in 1912 (Thacher, 1912, 11/27; Hale, 1912, 11/29), and Hale's son William attended Thacher's School starting in September of 1914 (Hale, 1914, 9/29). The month after William Hale arrived on Thacher's campus:

"A huge Sun dial is enswathed and finally set up after much squinting at the North Star. Now, by working out a certain formula to two or three decimal places, we can tell the exact time within a minute." (The Thacher School, 1915, p. 14)

George Hale lectured at the School twice that academic year: on February 6th, 1915 on the topic of 'Astronomy,' and again on March 29th, 1915 on the topic, 'What is the Use of Science?' (Hale, 1915, 2/15; Thacher, 1915, 2/15; The Thacher School, 1915, p. 19; Hale, 1915, 3/15; Thacher, 1915, 3/17).

First light for what would be the world's largest optical telescope for more than 30 years, the 100-inch Hooker telescope at Hale's Mt. Wilson Observatory, occurred on November 2nd, 1917 (Simmons, 1986), and that next May Thacher invited Hale for the third time to speak at the School's commencement exercises - this time at Hale's own son William's graduation-but for the third time Thacher was unsuccessful. Hale was away in New York at the time with plans to observe a total solar eclipse in Wyoming during William's graduation and therefore declined to attend (Thacher, 1918, 5/28; Hale, 1918, 5/29).

\section{Robert Andrews Millikan's Connections to The Thacher School}

Hale and Thacher's correspondence continued after William's graduation, and in July of 1921, Hale wrote by hand a compelling, 8-page letter to Thacher in which he described his successful efforts to bring Professor Robert Andrews Millikan from the University of Chicago to Caltech to become the Director of the Norman Bridge Physical Laboratory and the Chairman of a Governing Board of Trustees and Faculty (de facto president of the University): 
"My dear Mr. Thacher,

Probably you know by reputation my very intimate friend Professor Robert A. Millikan of the University of Chicago, whose record you will find in 'Who's Who.' Barring Michelson, who works as an individual, while Millikan is both a great investigator and leader of a school, the latter is far and away the ablest physicist in the country. Columbia, Yale, California, and several other universities have done their best to get him, but he has remained at Chicago, developing the greatest school of graduate students and research men in physics to be found this side of the Cavendish Laboratory at Cambridge University. At the outbreak of the war I selected him as Executive Officer of the National Research Council, and he played a leading and extraordinarily effective part in organizing the physicists of the country to deal with war problems. As the head of the Science and Research Division in the Signal Corps, which the National Research Council organized at General Squier's request, he established the sound ranging and meteorological services of the Army, set on foot and remained the leading factor in the submarine detection work of the Navy, and performed other war services of the most varied and successful character.

As you doubtless know, Millikan has spent one quarter of each year at the California Institute of Technology. I have now succeeded, after much work, in securing him permanently, together with additions to the Institute's funds for endowment and equipment exceeding four million dollars. This is the task I told you of last winter and the one to which I devoted as large a contribution as I could possibly afford to make personally.

Millikan is to be Director of the Norman Bridge Physical Laboratory, for which Dr. Bridge's gifts now amount to five hundred thousand dollars. He is also to be Chairman of a Governing Board of Trustees and Faculty. There will be no President of the Institute, as we wish to use Millikan's time for research and spare him the countless administrative duties of the office. But his will be the guiding hand in all matters of general policy.

Although we are not yet quite prepared to make an announcement of his appointment, Millikan is now preparing to move to Pasadena in the autumn. He has three sons, all exceptionally bright. The oldest is in Yale, the youngest at home, while the intermediate boy, Glenn, is doing exceptionally good work in the High School. He is a fine boy in every respect, and can be depended upon to make a first-class record in school and college. Millikan has just wired me to inquire whether there is any chance to get Glenn into The Thacher School in September. He would stay for two years and complete his preparation for college.

If you can manage this in any way I most sincerely hope you will do so, as the case is not an ordinary one, and as I am very anxious to have Millikan thoroughly satisfied with California. He will be one of the most eminent citizens of the state, and we must keep him here permanently. Incidentally, I may say that he is a most inspiring speaker, who would give admirable talks on visits to The Thacher School. You will find in the last number of "Science" his address at the reception to Marie Curie at the National Museum in Washington. I can easily secure any testimonials you may wish regarding the scholarship and personal qualities of his son Glenn.

Kindly wire me at my expense whether there is any chance for Glenn at the School, and also tell me the present cost of tuition, etc. We have just returned from three months in the east, nearly all of which time I devoted to securing Millikan and raising the funds necessary for his work here. Bill returned with us and begins work (for summer practice) in Reg (?)

Johnson's office tomorrow.

We all join in kindest regards to all of you.

Cordially yours,

George E. Hale” (Hale, 1921, 7/10) 
Glenn Millikan would matriculate at Thacher's School that September, and in October Thacher twice wrote Robert Millikan to invite him to visit his son at the School and to give a talk (Thacher, 1921, 10/6, 10/14). Robert Millikan visited the School in February of 1922 (Millikan, 1922, 1/20), bringing with him the Dutch physicist Hendrik Antoon Lorentz, who shared the Nobel Prize in Physics in 1902 with Pieter Zeeman for their work in magnetism and radiation phenomena, but there is no indication that either Millikan or Lorentz spoke to Thacher's students at that time.

In January of 1923, as Glenn Millikan prepared his application to Harvard University, Thacher twice wrote Robert Millikan to offer him a position on the School's first Board of Trustees as the School was to be incorporated the following year:

"I have a great favor to ask of you, and that is whether you will not serve as a member of our Board of Trustees when the school is incorporated.

We had hoped to have Dr. Hale join us on the Board, but he writes me that he cannot assume any more responsibilities. We naturally turn to you, feeling that you will give us what we are sure we should receive from him-very sympathetic cooperation and help and criticism and suggestion that would be always rousing us to better accomplishment." (Thacher, 1923a, $1 / 8)$

Millikan agreed, writing:

"I am, however, as you know, very greatly interested in the kind of work which the school is doing and particularly in what seems to me the extraordinarily wholesome atmosphere which you have succeeded in throwing about the boys who come to you... I think you may count upon my acceptance for a year or so..." (Millikan, 1923, 1/19)

(Millikan would continue to serve on Thacher's Board, however, until his death in 1953.) In
December of 1923, Millikan was awarded the Nobel Prize in Physics for his work in determining the charge on the electron, so The Thacher School's first Board of Trustees fortuitously included a Nobel Laureate in Physics. Thacher wrote Millikan on December 7th:

"Let me add my word of congratulation on the Nobel Prize. We were all greatly delighted, though not at all surprised to hear it." (Thacher, $1923 b, 12 / 7)$

Millikan and Lorentz again visited the Thacher campus in February of 1927, coincident with a Board of Trustees meeting, and again it appears as if the School missed an opportunity to hear them speak (Thacher, 1927a, 2/8; The Thacher School, 1927 , p. 16). Millikan's scientific work had turned from the electron towards the heavens in an effort to locate the source of high-energy radiation that had recently been identified, and he coined the term "cosmic rays" to refer to the energy and its source.

In April, Millikan appeared on the cover of Time Magazine, peering down a microscope with pen in hand. Underneath, the caption read, "Dr. Robert Andrews Millikan detected the cosmic pulse" (Time, 1927).

Hale was in poor health, but he maintained his connections to the School and wrote to Thacher in December of 1927:

\section{"Dear Mr. Thacher,}

I have now replenished my stock of little books and am able to comply with Mr. McBride's request received through Bill. The best answer I can give him as to the principal means of determining stellar distances may be found in the first chapter of 'The Depths of the Universe.' A later application of Shapley's method is explained in 'Beyond the Milky Way' (sent you last year, I think), in connection with Hubble's studies of the spiral nebulae. I am also sending 'The New Heavens' and 'Ten Years Work of a Mountain Observatory,' though the last is rather out of date. 
With warm regards and best wishes to you all for Christmas and the New Year from all of us, Yours ever,

George E. Hale” (Hale, 1927, 12/13)

Thacher replied with his grateful thanks for the books and an invitation for Hale to visit (Thacher, 1927b, 12/15).

The following year, Millikan went on to publish his paper on 'The Origin of Cosmic Rays' on October 1st of 1928 (Millikan and Cameron, 1928), and several days later on October 4th, he penned a letter to Thacher:

\section{"Dear Mr. Thacher:}

I have just returned from taking some cosmic ray observations in the mountains and find your letter of September 20th asking me to state what Saturday in October I could come to Ojai. On account of the pressure of accumulated work it is going to be very difficult, if not impossible, for me to get off a week-end this month unless, perchance, I might combine it with the obtaining of a little more needed data on the cosmic rays. For this purpose I am writing to ask what is the altitude above sea level of the school?

Thanking you very much for this information, which may possibly enable me to get a needed observation along with the pleasure of a visit to the school, I am

Cordially yours,

Robert A. Millikan” (Millikan, 1928a, 10/4)

Millikan's next letter summarized his plans to visit the campus with his family and to make his cosmic ray measurements on October 27th (Millikan, 1928b, 10/11)

\section{Edwin Powell Hubble's Connections to The Thacher School}

At about this same time Edwin Hubble's work on the 100-inch Hooker telescope at the Mt. Wilson
Observatory led him to publish his landmark series of papers in which he identified 'extra-galactic nebulae' and determined their distance-recessional velocity relationship that demonstrated the expansion of the Universe and allowed for an estimation of its age (Hubble, 1926; Hubble, 1929) These results apparently generated significant interest on the Thacher campus: organized school trips to see the 100-inch Hooker telescope at Mt. Wilson began in 1930 and would become an annual rite of passage for Thacher upperclassmen until the attack at Pearl Harbor and United States entry into World War II (Table 1).

Einstein visited the Mt. Wilson Observatory in January of 1931 to meet Hubble and see the telescope that he had used to effectively render Einstein's cosmological constant what he himself purportedly called his greatest blunder. During Einstein's visit, an iconic picture was taken of him at the eyepiece of the 100-inch telescope with Hubble, pipe in hand, standing just behind him, and Walther Adams (who succeeded Hale as Director of Mt. Wilson) standing next to Einstein (CLA, 1931). Just two months prior to when this photograph was taken, Thacher students chaperoned by Mr. Forest Cooke had stood on the very same spot and gazed through the same eyepiece at the heavens (Thacher, 1930, 11/1).

Thacher wrote Millikan on February 6th, 1931, to invite Einstein for a visit to campus (Thacher, 1931, 2/6), but apparently both Millikan and Einstein were too busy to come. Millikan, however, procured an inscribed and autographed portrait of Einstein that was given to the School at some point in 1932. The translated inscription reads, "To be undemanding and independent - that is freedom." The portrait currently hangs on the wall in our library archives.

Six months after the attack on Pearl Harbor and the United States entry into World War II, then Thacher Headmaster Anson Thacher (Sherman's brother) wrote to Robert Millikan, "I am going to have Dr. Edwin P. Hubble to speak at our Closing Exercises which pleases me very much" (Thacher, $1942,5 / 14)$. This reference is the only one we have 
yet been able to locate regarding Hubble's commencement address at Thacher prior to his actually giving it on June 6th, 1942, and it makes it sound as though inviting Hubble to speak was Anson Thacher's idea. We have to wonder, however, if it was Millikan who first suggested to Thacher that Hubble might be an appropriate commencement speaker. Millikan had chaired the School's semi-centennial celebration and delivered the commencement address in 1939, and he and Hubble knew each other from their work in science (there is a picture in Hubble's collection at the Huntington Library of Millikan and Hubble together with Einstein and a handful of other notable scientists, all in formal attire, at the Athenaeum club dinner for Einstein on February 4th during his famous visit to Pasadena in HLA, 1931). They also knew each other from their work together on the Huntington Library Board of Trustees, which Millikan chaired (Hubble took Hale's seat on the Board after Hale died in 1938, (Christianson, 1995, p. 264) ). And perhaps most importantly, Millikan and Hubble were both hawkish in their political views regarding the conflict in Europe. They had shared a podium together at a rally of the Southern California Chapter of the William Allen White Committee to Defend America by Aiding the Allies at the Riviera Country Club in 1940 where Hubble spoke very eloquently and passionately in his support of Britain (Christianson, 1995, p. 274-275). Given the similarity in tone of Hubble's Riviera address and his commencement address at Thacher we are inclined to believe it was Millikan who suggested to Anson Thacher that Hubble would be an appropriate commencement speaker after the United States' entry into the war, but we have yet to find any documentation that definitively confirms this opinion.

Hubble said in his commencement address at the School that June:

"We will win this war-not easily-not cheaply, but we will win, and some of you will play your part in the winning. Your generation will go out, with clear eyes and stout hearts, towards the making of a good world, a home where all men may live in peace and honor." (Hubble, 1942)

After the conclusion of the war there was one additional Thacher School trip to the Mt. Wilson Observatory in May of 1947, but attention was turning toward the new 200-inch telescope at Palomar. The El Archivero yearbook for the school year 1947-48 includes the November 19th reference, "Lewis (presumably 'upper upper' student Charlton Miner Lewis III) speaks on Mt. Palomar and the new 200-inch telescope" (The Thacher School, 1948, p. 25); Hubble appeared on the cover of Time Magazine with the caption, "Will Palomar's 200-inch eye see an exploding Universe? (Time, 1948); and the dedication of the 200-inch Hale telescope at the Palomar facility was celebrated in June (Christianson, 1995, p. 314)

In 1951, almost 9 years after he delivered his commencement address at The Thacher School, Hubble provided a reference letter for prospective student Daniel Crotty (Hubble, 1951, 4/2), who was accepted into the School and would go on to graduate in 1954. (It was correspondence from Daniel Crotty in 2013 and 2015 that first made us aware of Hubble's connections to the School and ultimately led to our locating the copy of his commencement address at the Huntington Library, which prompted us to dig further and uncover the Hale and Millikan connections. At the time of his attendance at Thacher, Crotty's parents, Homer and Ida, were close, personal friends of Edwin and Grace Hubble. They lived just across the street from each other - the Crottys at 1305 and the Hubbles at 1340 Woodstock Road in San Marino, CA, just a short walk from the Huntington Library and Gardens. The Hubbles and the Crotty family also occasionally vacationed together during the summers at the Rio Blanco Ranch in Colorado where fly-fishing and horseback riding were popular activities, and the Crottys were vacationing there at the ranch with Hubble and his wife when he suffered his heart attack in 1949; (Christianson, 1995, p. 329) 
When an 8-inch reflector in need of resurfacing was donated to the School, it was Crotty who thought to ask Hubble for his assistance in recoating the mirror, and we obtained, through Crotty, a copy of the letter in which Hubble wrote to him with instructions on how to maintain the aluminized mirror (Hubble, 1952). A copy of the thank you letter to Hubble from Newton Chase, Thacher Headmaster at the time, can be found in the Huntington Library's digital archives (Chase, 1952).

\section{Death of Icons and Birth of the SSP}

Both Hubble and Millikan died in the fall of 1953. In the same way that massive stars implode at the end of their life cycles to yield the most luminous objects in the Universe (supernovae), it might be said that the deaths of Millikan and Hubble in 1953, and the astronomical void left behind in their absence, prompted Thacher Headmaster Newton Chase to conceive in the late 1950's one of the true bright spots in Thacher's history of astronomy: the Summer Science Program (SSP).

The SSP document that contains the oldest available information in the chronology of the program is a summary, compiled in August of 2004 from the original documents, by Steve Cotler, whom John Briggs, archivist for the SSP, described as "an early alumnus of SSP and a key player in the reconstitution of the Program" (Briggs, pers. comm. 2017). Cotler's summary outlines the correspondence and communication related to the initial planning stages of the SSP (Cotler, 2004), and the key points to be gleaned from his outline are:

1. The Summer Science Program was Thacher Headmaster Newton Chase's brainchild.

2. Chase was instrumental in rallying both institutional and financial support for the program.

3. Early in its conception the academic program quickly evolved from a chemistry and physics curriculum tied to the College

Board's AP curricular content to a

mathematics and physics program involving the tracking of man-made satellites and near-Earth asteroids.

4. That despite strong interest in the program from the National Science Foundation, funding, equipment, and administrative support for the inaugural summer session were obtained from private sources:

- Funding was provided by the Helms and Ralph B. Lloyd Foundations (Lloyd was Daniel Crotty's grandfather and a Caltech trustee (Christianson, 1995, p. 349), so Newton Chase was able to capitalize on the Daniel Crotty-Edwin Hubble connection in order to raise funds for his fledging program).

- Equipment and curricular materials were supplied by Hughes Aircraft Corporation (Howard Hughes was a student at Thacher from 1921-1923 (The Thacher School, 1922, 1923)).

- Administrative support was provided by Caltech, Pomona College, and The Thacher School.

5. The inaugural program was completed under budget and was deemed successful by those involved.

Additional details on the SSP can be found elsewhere (Briggs, 2017), but it could reasonably be argued that the educational program it provided to its participants was 50 years ahead of its time, more sophisticated in its content, and more successful in stimulating student interest in science than any comparable summer program since. The SSP inspired and educated students in astronomy, math, physics, and computer science on the Thacher campus for 40 years (until mounting financial losses absorbed by the School after NSF support for summer science programs was 
discontinued in 1981 prompted a change to a more financially viable summer program in 1999).

After the first several years of operation of the SSP, an observatory was erected on Thacher's campus in April of 1965 under the direction of UCLA's George Abell in order to house a 24-inch astrograph built by Caltech (see Figure 1 this paper, Aller, 1965, p. 14-18). The observatory was used by Thacher students as well as by undergraduate and graduate students from a variety of SSP-affiliated southern California colleges and universities for several decades. The most historically significant of these collaborations is documented in a letter dated September 30th, 1994, from William Baity, UCSD professor and Project Manager for the Faint Object Spectrograph on the Hubble Space Telescope, to Elizabeth Bowman, Thacher's librarian at the time. In his letter Baity thanked Bowman for loaning to him archival photographs of the observatory's construction for a UCSD-TV documentary on black holes, the Hubble Space Telescope, and the work he was doing at UCSD. He went on to write:

"You may be interested in the role The Thacher School played in this particular area. In the early 1970's, when the Space Telescope was only a gleam in some astronomer's eye, a graduate student at UCSD, ED Beaver, had, upon the instructions of his mentor, Prof. Carl McIlwain, developed a new type of photon detector. This device, name the Digicon, promised important improvements in image placement and stability, as well as an impressively low background noise level, which would permit observations of unparalleled sensitivity, so that the mysteries of the cosmic depths might be investigated. This device was to be a 1-dimensional spectrograph, putting out spectra which appear to be less interesting than pictures, but which form the backbone of modern astrophysics. There was a little problem: Ed and Carl were not known as observational astronomers, and would have to prove the value of their device somewhere before they would be allowed to use the larger telescopes.

Fortunately, the 24-inch telescope that UCLA had placed at Thacher was available, and Ed recalls a very pleasant observing session at Thacher with the Digicon. The good results obtained at Thacher allowed access to the UC Lick Observatory and the U Texas McDonald Observatory. Having a working detector and state-of-the art results allowed UCSD to snatch the contract award for the Faint Object Spectrograph for the Space Telescope from under the nose of a heavily favored Harvard consortium! The group planning the other, High Resolution, spectrograph was so impressed that they opted to use the Digicons as well. The result is that all four spectrographic detectors on board the Hubble Space Telescope are Digicons. And The Thacher School was right there at the beginning!" (Baity, 1994, 9/30)

\section{Modern Efforts}

After the School ended its relationship with the SSP in 1999 the telescope was removed from the observatory and the building was repurposed as faculty housing. Initial efforts to reclaim the observatory for astronomy began with Vyhnal's promotion to Science Department Chair in the 2006-07 academic year; astronomy classes were added to our science curriculum in 2008; the program gained traction in the fall of 2009 with the donation and installation of a 1993 model, Newtonian equatorial mount, Meade 16-inch reflector in the observatory. At this point in time, we knew virtually none of the historical information documented in this paper, which has only come to full light in the last few years.

Fundraising efforts for our observatory began in earnest in 2011 with a report to Thacher's governing Board of Trustees (Vyhnal and Swift, 2011). Swift joined the faculty in 2014 and continued pitching his ideas for a renovated observatory to our administration and board. Funding was secured in April of 2016 and the Thacher Observatory underwent a major renovation in the fall of 2016 under the supervision 
of Paul Gardner of Observatory Systems (see Figure 2 this paper, O’Neill et al., 2016; Gardner, 2017), which included a new, shrink-wrapped and weatherproof roof, a fully robotic Ash Dome, a Plane Wave CDK 700 telescope, and an Andor iKon L-series CCD camera. First light for the renovated facility was celebrated on December 10th, 2016 (O’Neill et al., 2017).

Our students are learning the fundamentals of observational astronomy with our telescope and CCD camera as well as scientific programming, primarily in python. Interest in astronomy on our campus has blossomed over the last 4 years, as reflected in healthy student enrollments in our introductory astronomy classes, our Research Astronomy class, and our Data Science class (see Table 2). In addition, membership in our Astronomy Club is robust with 30 students actively participating currently. Several student projects have recently been completed (Klink et al., 2016) or are ongoing (Swift, 2017), including full characterization of the CCD camera, determination of the zero-point magnitude of the observatory, a search for Planet 9 (Edwards et al., 2017), deep field imaging of galactic mergers and their tidal tails, and precise photometric measurements of Tabby's Star and several transiting exoplanets and eclipsing binary stars (Swift et al., 2017). In the most recent follow-up study of Tabby's Star, Thacher Observatory was featured as one of the worldwide collaboration of observatories that caught the first light curve dip seen since the Kepler Space Mission (Boyajian et al., 2018).

We are proud of and humbled by The Thacher School's rich historical legacy in astronomy education and research, and we are immensely gratified that in renovating the observatory and establishing an active student research program at the school we have been able to reclaim and preserve this rich legacy for future generations of Thacher students.

\section{Acknowledgements}

We are grateful to Daniel Crotty (Thacher alum, 1954), Nancy O'Neill (mother of one of our astronomy students), Bonnie LaForge (Thacher Archives), Loma Karklins (Caltech Archives), John Briggs (SSP Archives), Richard Bowdon (SSP Executive Director) and Stephanie Arias, Laura Rips, and Samuel Wylie (Huntington Library Archives) for their help in obtaining relevant historical information. The manuscript benefited from thoughtful and constructive reviews by Ross Cutts and an anonymous reviewer.

Most of the information compiled for this history was obtained from a handful of sources:

- Thacher Library Archives (TLA)

- Caltech Library Archives (CLA)

- Huntington Library Archives (HLA)

- Summer Science Program Archives (SSPA)

Authors of the historical correspondence referenced below are identified by their initials::

- $\mathrm{SDT}=$ Sherman Day Thacher

- $\mathrm{GEH}=$ George Ellery Hale

- $\mathrm{RAM}=$ Robert Andrews Millikan

- $\mathrm{ECH}=$ Evelina Conklin Hale

- $\mathrm{AST}=$ Anson Stiles Thacher

- $\mathrm{EPH}=$ Edwin Powell Hubble

- $\mathrm{NKC}=$ Newton Kimball Chase

Most all of the historical correspondence has been digitally imaged as pdfs and may be obtained from the first author. 


\section{References}

Aller, L. (1965). TLA, Observatory Folder, "UCLA Installs Telescope at Thacher" Thacher Magazine, Spring, p14-18. Includes associated photographic prints.

Baity, W. A. (1994). TLA, Observatory Folder, William A. Baity to Elizabeth Bowman.

Boyajian, T. S., Alonso, R., Ammerman, A., Armstrong, D., Ramos, A. A., Barkaoui, K., Beatty, T. G., Benkhaldoun, Z., Benni, P., Bentley, R. O., et al. (2018). The First Post-Kepler Brightness Dips of KIC 8462852. The Astrophysical Journal Letters, 853(1):L8.

Briggs, J. (2017). Summer Science Program. Talk presented at Robotic Telescopes, Student Research and Education Conference, San Diego, CA.

Chase, N. (1952). "Newton Chase, Headmaster of the Thacher School, writes to Edwin P Hubble to thank him", HLA, Edwin Hubble papers, mssHUB 222.

Christianson, G. E. (1995). Edwin Hubble: mariner of the nebulae. University of Chicago Press.

CLA (1931). Einstein with Edwin Hubble and Walter Adams at the Mount Wilson Observatory. ID 1.6-16.

Cotler, S. (2004). Summer Science Program History. Summer Science Program Archives, Timeline of 'Early Correspondence' Folder, summarized by Steve Cotler, 2004, as shared by Richard Bowdon.

Edwards, N., Kirkpatrick, L., O'Neill, K., Yin, Y., Wood, A., and Swift, J. (2017). A Search for Planet 9 at the Thacher Observatory. In American Astronomical Society Meeting Abstracts, volume 229.

Gardner, P. (2017). Observatory Systems. Talk presented at Robotic Telescopes, Student Research and Education Conference, San Diego, CA.
Hale, G. E. (1912). CLA, George Hale Papers, Box 40, Sherman Day Thacher Folder, GEH to SDT.

Hale, G. E. (1914). CLA, George Hale Papers, Box 40, Sherman Day Thacher Folder, GEH to SDT.

Hale, G. E. (1915). TLA, William Hale Student Folder, GEH to SDT.

Hale, G. E. (1918). TLA, William Hale Student Folder, GEH to SDT.

Hale, G. E. (1921). TLA, Glenn Millikan Student Folder, GEH to SDT.

Hale, G. E. (1927). TLA, William Hale Student Folder, GEH to SDT.

HLA (1931). "Photograph of Albert Einstein, Edwin Powell Hubble, and others at the Athenaeum", Edwin Hubble papers, mssHUB1058.

Hubble, E. (1926). No. 324. Extra-galactic nebulae. Contributions from the Mount Wilson Observatory/Carnegie Institution of Washington, 324:149.

Hubble, E. (1929). A relation between distance and radial velocity among extra-galactic nebulae. Proceedings of the National Academy of Sciences, 15(3):168-173.

Hubble, E. P. (1942). (HLA), 'The Years Ahead", hdl.huntington.org, Edwin Hubble papers, mssHUB 71, http://hdl.huntington.org/cdm/compoundobject/ collection/p15150coll7/id/5266/rec/2 Web. 4/11/2017.

Hubble, E. P. (1951). TLA, Daniel Crotty Student Folder, EPH to NKC.

Hubble, E. P. (1952). "Edwin P Hubble writes to Dan Crotty", HLA, Edwin Hubble papers, mssHUB 431.

Klink, D., Swift, J., Muirhead, P. S., Johnson, J. A., Han, E., and Shan, Y. (2016). On the Recovery of Stellar Parameters from Eclipsing Binary 
Data. In American Astronomical Society Meeting Abstracts, volume 227.

Millikan, R. A. (1922). TLA, Glenn Millikan Student Folder, RAM to SDT.

Millikan, R. A. (1923). TLA, Robert Millikan Trustee Folder, RAM to SDT.

Millikan, R. A. (1928a). TLA, Robert Millikan Trustee Folder, RAM to SDT.

Millikan, R. A. (1928b). TLA, Robert Millikan Trustee Folder, RAM to SDT.

Millikan, R. A. and Cameron, G. H. (1928). The origin of the cosmic rays. Physical review, 32(4):533.

O’Neill, K., Osuna, N., Edwards, N., Klink, D., Swift, J., Vyhnal, C., and Meyer, K. (2016). The Renovation and Future Capabilities of the Thacher Observatory. In American Astronomical Society Meeting Abstracts, volume 227.

O'Neill, K., Yin, Y., Edwards, N., and Swift, J. (2017). First Light of the Renovated Thacher Observatory. In American Astronomical Society Meeting Abstracts, volume 229.

Simmons, M. (1986). Building the 100inch telescope. Mount Wilson Observatory Association. https://www.mtwilson.edu/ building-the-100-inch-telescope/ Accessed 8 July 2017.

Swift, J. (2017). Exoplanet Transit Program at The Thacher School. Talk presented at Robotic Telescopes, Student Research and Education Conference, San Diego, CA.

Swift, J., Han, E., Ding, J., O’Neill, K., Lawrence, Y., Klink, D., Muirhead, P. S., and Shan, Y. (2017). Does the Eclipsing Binary KIC 10935310 Contain a Massively Inflated M Dwarf? In American Astronomical Society Meeting Abstracts, volume 229.

Thacher, A. S. (1942). TLA, Robert Millikan Trustee Folder, AST to RAM.
Thacher, S. D. (1906). CLA, George Hale Papers, Box 40, Sherman Day Thacher Folder, SDT to GEH.

Thacher, S. D. (1911). CLA, George Hale Papers, Box 40, Sherman Day Thacher Folder, SDT to GEH.

Thacher, S. D. (1912). CLA, George Hale Papers, Box 40, Sherman Day Thacher Folder, SDT to GEH.

Thacher, S. D. (1915). TLA, William Hale Student Folder, SDT to GEH.

Thacher, S. D. (1918). TLA, William Hale Student Folder, SDT to ECH.

Thacher, S. D. (1921). TLA, Glenn Millikan Student Folder, SDT to RAM.

Thacher, S. D. (1923a). TLA, Glenn Millikan Student Folder, SDT to RAM.

Thacher, S. D. (1923b). TLA, Robert Millikan Trustee Folder, SDT to RAM.

Thacher, S. D. (1927a). TLA, Robert Millikan Trustee Folder, SDT to RAM.

Thacher, S. D. (1927b). TLA, William Hale Student Folder, SDT to GEH.

Thacher, S. D. (1930). TLA, William Hale Student Folder, SDT to ECH.

Thacher, S. D. (1931). TLA, Robert Millikan Trustee Folder, SDT to RAM.

The Thacher School (1915). TLA, El Archivero Yearbook, The Thacher School, Nordhoff, CA.

The Thacher School (1922). TLA, El Archivero Yearbook, The Thacher School, Nordhoff, CA, p.11.

The Thacher School (1923). TLA, El Archivero Yearbook, The Thacher School, Nordhoff, CA, p9. 
The Thacher School (1927). TLA, El Archivero Yearbook, The Thacher School, Nordhoff, CA.

The Thacher School (1948). TLA, El Archivero Yearbook, The Thacher School, Nordhoff, CA, $\mathrm{p} 25$.

Time (2/9/1948). TIME Magazine Cover: Edwin P. Hubble.

Time (4/25/1927). TIME Magazine Cover: Robert A. Millikan.

Vyhnal, C. and Swift, J. (2/2/2011). TLA, Report on the Status of Thacher's Astronomy Program and Observatory with Opportunities for Donors, 10 pages. 
Thacher School Annual Trips to Mt. Wilson Observatory in Pasadena

\begin{tabular}{|c|c|c|c|c|c|c|}
\hline $\begin{array}{l}\text { School } \\
\text { Year }\end{array}$ & $\begin{array}{c}\text { Date } \\
\text { of Trip }\end{array}$ & $\begin{array}{l}\text { \# Students } \\
\text { Attending }\end{array}$ & $\begin{array}{l}\text { Thacher Faculty } \\
\text { Chaperones }\end{array}$ & $\begin{array}{c}\text { Mt. Wilson } \\
\text { Staff } \\
\text { Mentioned }\end{array}$ & $\begin{array}{c}\text { El } \\
\text { Arch } \\
? \\
\end{array}$ & $\begin{array}{c}\text { The } \\
\text { Notes? }\end{array}$ \\
\hline $1930-31$ & $11 / 21 / 30$ & $10-12$ & Mr. Forest Cooke & Dr. Adams & $\mathrm{X}$ & $\mathrm{X}$ \\
\hline $1931-32$ & $1 / 29 / 32$ & 25 & $\begin{array}{l}\text { Mr. Owen MacBride, } \\
\text { Mr. Albert Norris }\end{array}$ & Mr. Hickox & $\mathrm{X}$ & p1 \\
\hline $1932-33$ & $3 / 3 / 33$ & $?$ & $?$ & Dr. Adams? & p28 & $\mathrm{X}$ \\
\hline 1933-34 & $3 / 9 / 34$ & 13 & Mr. Morgan Barnes & Mr. Hickox & p29 & p1 \\
\hline $1934-35$ & $3 / 1 / 35$ & 10 & $\begin{array}{l}\text { Mr. Morgan Barnes } \\
\text { Mr. William Morwood }\end{array}$ & & $\mathrm{X}$ & p3 \\
\hline $1935-36$ & $1 / 31 / 36$ & $?$ & ? & & p41 & $\mathrm{X}$ \\
\hline $1936-37$ & $2 / 12 / 37$ & 15 & Mr. Anson Thacher & & $\mathrm{X}$ & p1 \\
\hline $1937-38$ & $2 / 24 / 38$ & $?$ & $?$ & & $\mathrm{X}$ & p3 \\
\hline 1938-39 & $1 / 27 / 39$ & $?$ & Mr. Sidney Treat & Mr. Hickox & $\mathrm{X}$ & p1 \\
\hline $1939-40$ & $2 / 9 / 40$ & 16 & Mr. Newton Chase & Mr. Hickox & $\mathrm{X}$ & p5 \\
\hline $1940-41$ & $1 / 31 / 41$ & 16 & $\begin{array}{l}\text { Mr. Durand } \\
\text { Echeverria }\end{array}$ & & p23 & p1 \\
\hline $1946-47$ & $5 / 30 / 47$ & 'several' & $?$ & & p31 & $\mathrm{X}$ \\
\hline $1947-55$ & \multicolumn{4}{|c|}{ no evidence of trips in El Archivero calendars } & $\mathrm{X}$ & \\
\hline
\end{tabular}

Table 1. The Thacher School began taking their 'upper upper' boys on annual trips to Pasadena to visit the Mt. Wilson Observatory and the Huntington Library starting in the 1930-31 school year. Caltech was also added as a destination starting in the 1937-38 school year. Thacher chaperons in bold were either current or eventual Heads of School. Documentation of the trips (denoted by the page number in the reference) comes from the El Archivero yearbook calendars and The Thacher Notes school newspapers (an X in the respective column indicates no mention of the trip was found in that source). The first trip was confirmed in Thacher's correspondence with the Hales in late October and early November of 1930. 


\section{Recent Astronomy Program Enrollments at The Thacher School}

\begin{tabular}{|c|c|c|c|c|}
\hline $\begin{array}{c}\text { Academic } \\
\text { Year }\end{array}$ & $\begin{array}{c}\text { Introductory } \\
\text { Classes }\end{array}$ & $\begin{array}{c}\text { Research } \\
\text { Class }\end{array}$ & $\begin{array}{c}\text { Independent } \\
\text { Study Projects }\end{array}$ & Instructor \\
\hline $2008-09$ & 5 & not offered & not offered & Harris \\
\hline $2009-10$ & 6 & & & Vyhnal \\
\hline $2010-11$ & 7 & & & Vyhnal \\
\hline $2011-12$ & not offered & & & Vyhnal \\
\hline $2012-13$ & 8 & & & Vyhnal \\
\hline $2013-14$ & 4 & & & Swift \\
\hline $2014-15$ & 21 & & 1 & Swift \\
\hline $2015-16$ & 21 & 9 & 2 & Swift \\
\hline $2016-17$ & 23 & 10 & 1 & Swift \\
\hline $2017-18$ & 6 & 9 & To be determined & Swift \\
\hline $2018-19$ & To be determined & 12 & & \\
\hline
\end{tabular}

Table 2. Numbers represent students enrolled in our astronomy classes and demonstrate the development and growth of our astronomy program. Our introductory classes have varied in content, structure and instructor over recent years, but all were designed with the purpose of exposing our students to the science of astronomy and stimulating their interest in the discipline. The program took big steps forward with the addition of Swift to our faculty in 2014 and the renovation and automation of our observatory in 2016. Those students interested in pursuing additional study beyond our introductory courses can conduct research under close faculty supervision in our Astronomy Research class or in independent study projects undertaken outside of the daily academic schedule. Facility with quantitative data analysis and computer programming in python is also developed in a Data Science class that has enrolled 4 students in each of the last 2 academic years. 
Installation of the 24-inch Astrograph at the Thacher Observatory, circa 1965.

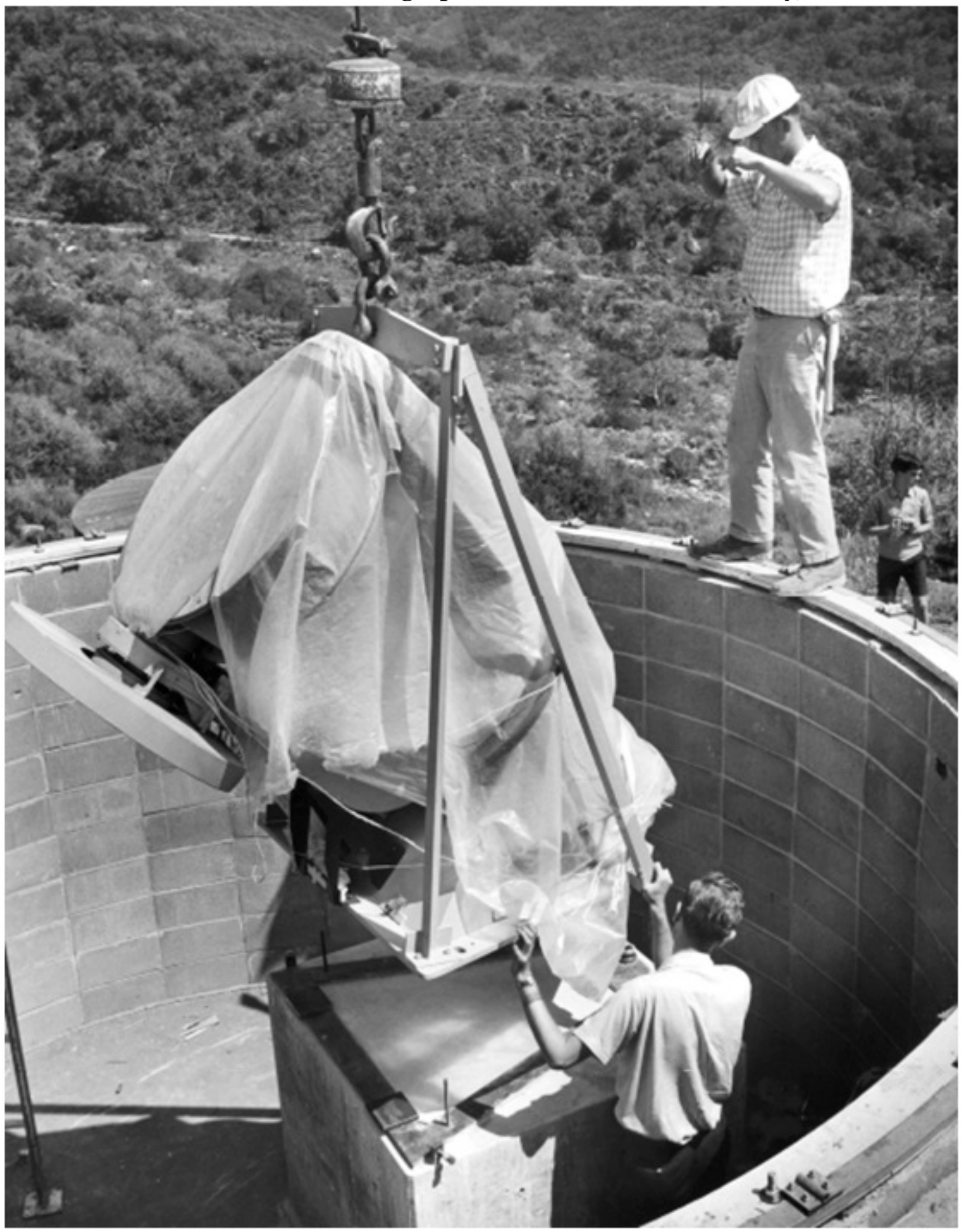

Figure 1. A 24-inch astrograph built by Caltech is installed in the Thacher Observatory built by UCLA in 1965. Image source: Thacher Library Archives, Observatory Folder. 


\section{Renovation of the Thacher Observatory, 2016}

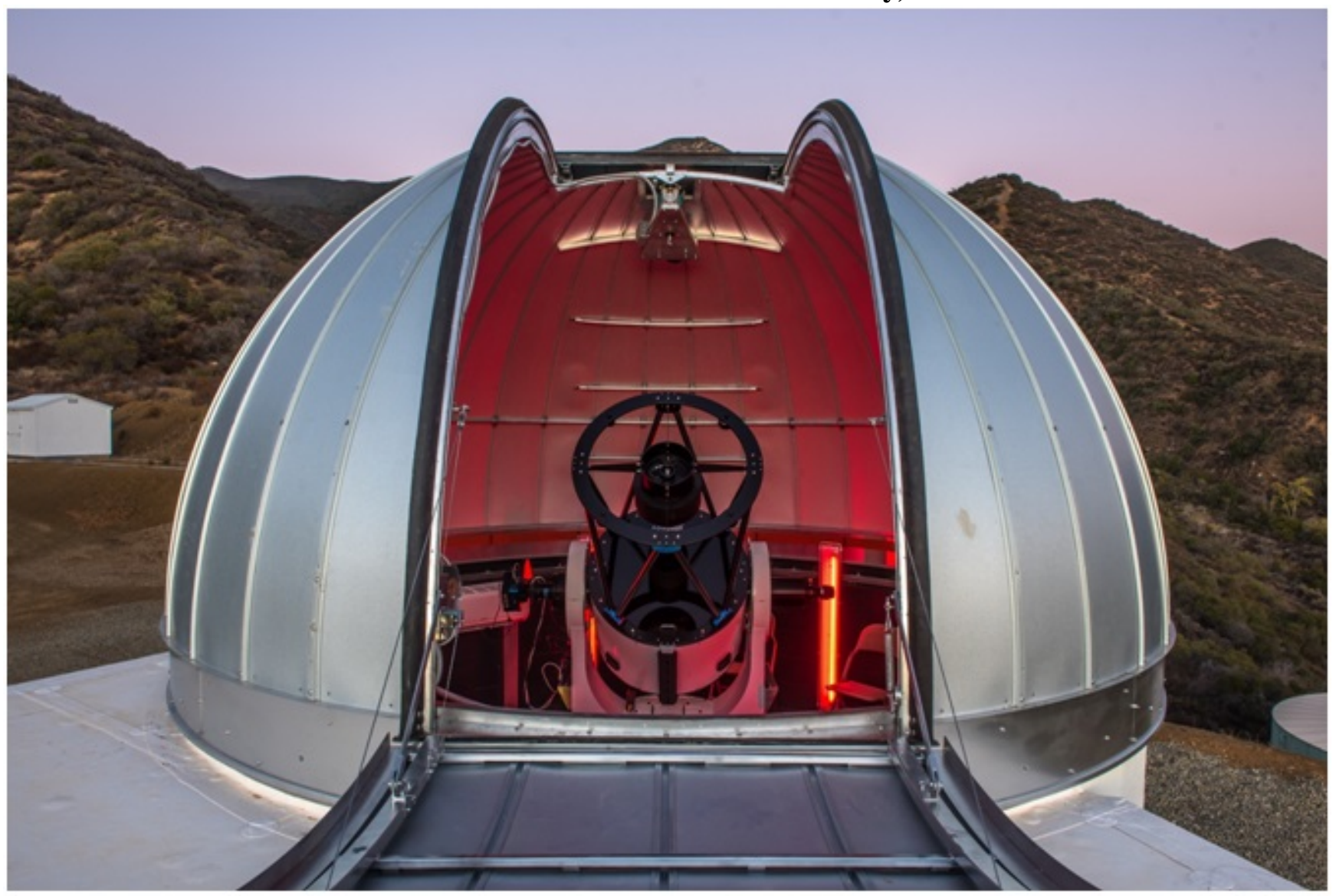

Figure 2. The Thacher Observatory underwent a complete renovation in the fall of 2016, which included installation of a shrink-wrapped and weatherproof roof, a new, fully robotic, Ash Dome, a Plane Wave CDK 700 telescope, and an Andor iKon L-series CCD camera. Photo credit: Paul Gardner, Observatory Systems. 